\title{
\#nofilter: Online Personas and The Negative Impacts of Social Media on Young Adults' Self-esteem
}

\author{
Jessica Godwin \\ English of Creative Industry, Faculty of Languages and Literature, Petra Christian University, \\ Siwalankerto 121-131, Surabaya 60236, INDONESIA \\ E-mail: jessicagodwin96@gmail.com
}

\begin{abstract}
My novel \#nofilter follows Mia, a photo model who is pretty famous on the social media platform Instagram, as she meets Kyle, her online boyfriend for the first time. In an effort to earn other people's acceptance, Mia has been building a perfect online persona. However, after meeting Kyle, it is revealed that she is not who she portrays herself to be. As my work revolves on how social media affects someone's self-esteem, hopefully it can help the readers learn to love themselves and do not depend their self-esteem on others. Specifically, I focus on how Mia maintains an idealized online persona in order to cope with her low self-esteem and earn other people's acceptance, how the contrast between Mia's online and real life personas causes her relationship with Kyle to crumble, and how Mia learns to love herself by accepting her weaknesses and acknowledging her positive qualities. For that reason, I use Contingencies of Self-esteem theory by Jennifer Crocker and Connie T. Wole, the Social Comparison theory, and the Presentation of Self in Everyday Life by Erving Goffman. Set in the early years after college, I use New Adult genre and the sub-genre Contemporary Romance to explore Kyle and Mia's romantic relationship.
\end{abstract}

Keywords: Social media, Instagram, self-esteem, online persona, New Adult, Contemporary Romance

\section{INTRODUCTION}

Social media has become an essential part of today's society, including in Indonesia. Nowadays, most things are digitized. Specifically, $68 \%$ of Indonesians prefer to "complete task digitally whenever possible" (Sholihin, 2018). According to We Are Social (2018), a global media company based in the UK, the number of social media users in Indonesia grows by 24 million (23\%) compared to the previous year (Sholihin, 2018). Essentially, social media is no longer just about networking; it keeps people up to date. In 2017, Global Web Index lists top 10 reasons for using social media, which, other than networking purposes include: "to stay up-todate with news and current events (41\%); to fill up spare time (39\%); to find funny and entertaining content (37\%)" (Valentine, 2017).

However, while logging into social media provides users with a continuous stream of information (e.g. recent news, status updates, newly uploaded pictures, friends' posts, etc), it may serve as a stimulus for social comparison. As previous research has pointed out, people tend to display their 'idealized version of self' on social media (Zhao, Grasmuck, \& Martin, 2008). In other words, they tend to share the positive sides of their lives, while keeping the rest hidden. Therefore, as stated in the social comparison theory, upon seeing the updates online, sometimes social media users cannot help comparing them to their own, which may affect one's self-esteem.

Social comparison itself is a theory stating that we determine our own social and personal worth based on how we stack up against others we perceive as somehow faring better or worse 
(Psychology Today, 2018). It happens because humans supposedly possess a fundamental drive to compare themselves with others, which serves a variety of functions, such as fulfilment of affiliation needs, self-evaluation, decision-making, source of inspiration, and regulation of emotions and well-being (Vogel, Rose, Roberts, \& Eckles, 2014). It can go both ways: upward (others are better) and downward (we are better). However, in the case of social media, seeing other people's highlights - the carefully constructed content - may lead people to think that others are living a better life than their own, i.e. upward social comparison, hence affecting how users perceive their own worth, and potentially lower their self-esteem.

Meanwhile, self-esteem is an individual's overall subjective evaluations on his or her own worth, whether they are positive or negative (Hewitt, 2009). The concept of self-esteem itself was first proposed by William James in his book The Principles of Psychology (1890). James believed that "our self-feeling (i.e. self-esteem) in this world depends entirely on what we back ourselves to be and do" (James, 1890). Since then, many researchers have taken on his lead, causing self-esteem to have a "prolific history" in psychology. Additionally, one of the reasons of its popularity being that "self-esteem has been shown to have a pervasive and powerful impact on human cognition, motivation, emotion, and behavior" (Campbell \& Lavallee, 1993).

For those with low or fluctuating self-esteem, social media can be an endless social comparison experience. When they see that others are better (e.g. others get more likes or followers), then they might see themselves as inferior. Similarly, even if they succeed in acquiring an idealized online persona, they may end up having low self-esteem anyway, as the social comparison process does not necessarily stop, and may even cause more dependence on social media, as explained earlier. Essentially, social media users, especially young adults who invest most of their time there, have to remember that what they see in social media is never the whole storythere can be alterations and even fabrications in order for those 'online personas' to be as ideal as possible. Hence, it is important that I convey this message through my creative work.

Among the many social media platforms available, a recent research has revealed that Instagram is the worst social media for young people's mental health. The research is called Status of Mind, conducted by the Royal Society of Public Health, UK, in which teenagers and young adults aged 16-24 took part in. Specifically, its use has been linked to issues such as body image, lack of sleep, and FOMO (Widiartanto, 2017). Hence, I would like to focus on this particular social media platform.

For the form, I believe a novel is the best option for me and my work because there are not many novels, especially in Indonesia, which explore the effects of social media on one's selfesteem. Moreover, when I try to find novels on social media, most of them cover the issue of cyber-bullying and/or assuming different identities, which leads to either murder or suicide. In Indonesia itself, there is the book The Last Crowd (English edition of Kerumunan Terakhir, 2016), by Okky Mandasari (2017), which claims to be "the first Indonesian novel that explores the pressing issue of human existence in an era where modern technology consumes our existence" (Mandasari, 2017). Therefore, I see this as a chance to present more creative works concerning this issue, and by writing this novel, I am providing something new to the readers because the issue I am portraying has not been tackled a lot.

Additionally, evocative language of a novel has the power to awaken readers' imagination to various sensations (Calafiore, 2014). Both a script and screenplay emphasize actions more than feelings, whereas in a novel, the descriptions, which may take several lines and paragraphs, allow the readers to actually feel with the characters, as opposed to just seeing the action. Essentially, although each form has its own advantages, I believe novel is the most suitable form I could use for my story. 
Meanwhile, for the genre, I plan to explore my story through the genre New Adult and subgenre Contemporary Romance. New Adult is a genre which focuses on characters between the ages of eighteen to twenty-six, sometimes even to thirty years old, which are also commonly referred to as Millennials. As the name suggests, this genre is for those who are transitioning from being teenagers to adults - namely the 'middle' part of it where they may feel the need to redefine themselves from the values their parents have taught them. I choose this genre because this so-called self-discovery period is what I would like to explore more- that social media and its effects on self-esteem are also relevant to young adults, not just teenagers.

On the other hand, the Contemporary Romance genre deals with a romantic relationship between two characters set in the present time (Lind, 2015). Generally, the story starts with the two future love interests meeting each other; it is also possible that they have already known each other prior to the start of the story. Then, the story will either explore one of the two winning over the other, or both of them maintaining their relationship despite many conflicts between them. Finally, the conflicts will be resolved with the two of them acknowledging their feelings. However, happy endings are not the absolute outcome (Lind, 2015). I believe feelings and relationships are important factors for someone in discovering themselves and learning to love themselves as they are. Therefore, the genre New Adult and sub-genre Contemporary Romance works best for me and my creative work in addressing the issue on self-esteem and social media.

Through my creative work, I am to show that social media users often display the 'perfect' and idealized persona of themselves online to cope with their low self-esteem and seemingly 'ordinary' life. Furthermore, that action could possibly affect their real-life relationships outside social media, especially when the contrast between the two personas is strong. For instance, the other party could feel like they have been lied to, and questions the relationship. Fortunately, it is possible for people with contingent self-esteem to love themselves by embracing both their strengths and weaknesses, instead of depending their worth on others.

My creative work will revolve around the life of Mia, who builds an online popularity on the social media platform Instagram. However, in contrast to the seemingly perfect online persona that she is, Mia actually has low self-esteem and has never been confident with herself. That is why, when Kyle, her online boyfriend, wants to meet her, she either declines or avoids the subject, as she is worried that he will come to hate her when he finds out the truth.

\section{OUTLINE OF CREATIVE WORK}

\subsubsection{Theme}

The main message I would like to convey with this story is that social media could affect our self-esteem negatively, especially for people with low self-esteem, due to social comparison. Specifically, I will convey the message through the existence of online personas, and how they affect real-life relationships.

The novel will show Mia's struggle with her own self-worth, and the depression she experiences because of it. Specifically, she cannot stop comparing herself to other people on social media, despite earning quite a popularity in there herself. As a result, she pushes herself, often beyond her limits, to continue being her 'perfect' online persona. When none of her efforts seem satisfactory, she often falls into anxiety and depression, which causes her to harm herself at times. At the same time, she is also hiding her true, vulnerable self from Kyle, so their meeting threatens her self-esteem, and later their relationship, too. The contrast between her two personas makes the two of them, especially Kyle, question their relationship, possibly ruining it. 


\subsubsection{Plot}

On her Instagram, Mia has thousands of followers liking her content, and always seems to be surrounded by friends. She even has a loving and supportive boyfriend, Kyle, who she meets and dates online. Yet, she always seems to be against the idea of meeting him for real and avoids the topic whenever it comes up. Worse yet, when Kyle shows up for real in Surabaya to see her, hoping it will be a pleasant surprise, she starts avoiding him.

As the two of them interact more, it turns out that the reality is different from what Kyle and Mia's followers see on her social media. She has depression and anxiety, and is even on medications for them. After Kyle finds out, Mia tearfully confesses to him that her experiences of growing up in the shadow of her "perfect" sister Rena causes her to have low self-esteem, and her online persona is one of the ways she copes with it. While it clearly does more bad than good, she cannot bring herself to stop, as she needs the recognition from others and, now that they have met, him. Despite everything, Mia hopes that Kyle would stay with her, as her love for him, if nothing else, is real. Unfortunately, he leaves her in anger.

After that, Mia decides to push everyone away, including Kyle and her best friend, Vero. She deletes her Instagram, and refuses to respond to anyone's calls or messages. She locks herself in her room, sobbing, thinking she has lost everything, and is ready to kill herself. Yet, instead of feeling empty like she first expects she would, Mia actually has time to think about what she actually wants. Then, triggered by some messages and phone calls from what is supposed to be a broken phone, she reflects on her life and starts thinking about herself, and not others, like she has always done. Later on, to Mia's surprise, Rena comes and helps taking care of her, until one day Mia decides to go to London with her for a fresh start.

\subsubsection{Characters}

\section{Main Characters:}

\section{Mia Gunawan}

Age: 24 years old

Mia has long black and straight hair, with brownish small and round eyes. Additionally, she is about 160 centimeters in height. She likes to stay inside her room for hours, especially after she has been out for the whole day. She cries and gets shaken rather easily, and usually will try to hold it by biting her lip. Although she tries her hardest to seem outgoing and cheerful, she gets anxious very easily, especially when communicating with others. Mia is the younger daughter in a four-family middle class Indonesian household living in Surabaya. She is only two years younger than her sister, Rena. As a child, people often compare her to Rena, who excels in both academics and athletics.

\section{Kyle Hartono}

Age: 25 years old

Kyle is about 180 centimeters in height, with medium build. He has black, a little slanted eyes. Kyle is an only child from a middle class Indonesian family living in Jakarta. He is independent, responsible, and is very outgoing. His passion for photography and travelling leads him to becoming a freelance photographer, which allows him to work in various places in Indonesia. 


\section{Supporting Characters:}

Rena Gunawan

Age: 27 years old

Mia's 'perfect' older sister who excels in pretty much everything she does. This leads her to continuing her study abroad, and eventually working in London. Despite the two of them being compared a lot by their family and friends, the sisters have a very close relationship growing up. However, they become distant as Rena leaves for college and seldom returns home to Indonesia.

Vero

Age: 24 years old

Mia's best friend since middle school, and is pretty much her only 'real' friend. She is about 165 centimeters tall, with long straight hair and brownish eyes. Vero likes to dye her hair, and she experiments a lot with colors. Similarly, she has a very bright and positive personality - she also will not hesitate to say whatever is in her mind, as long as she believes that she is right.

Toni Prakasa

Age: 35 years old

A photographer who works a lot with Mia and a friend of Kyle's. Toni is about 170 centimeters tall with a medium build and a tanned skin. His shoulder-length curly black hair is often messy, although he sometimes ties it as a small ponytail. Mature and responsible, he treats both Mia and Kyle like younger siblings. His wife's name is Dewi.

\section{Extra Characters:}

Mia's high school friends

A group of five girls who were Mia's classmates in high school. Although they were not very close back then, they suddenly started to hang out a lot with Mia once she became 'famous'. Additionally, they seem to benefit from Mia, especially when she makes Instagram posts and stories with them.

Fellow models

Five fellow models who work in the same agency as Mia. Mia thinks that all of them are more famous than her, even those who started around the same time as her, and she always feels inferior around them. They are Tiara (27 years old), a veteran model, who is one of the most successful in the agency; Meliana (26 years old), a former child actress who is now more active in modeling; Farah (25 years old), a model and selebgram; and Tania (23 years old), a model who started out and is more active as a Youtuber.

Leony Gunawan

Age: 52 years old 
Mia's mother. She is about 160 centimeters in height and has a small build. Like Mia, her black hair is straight and long. She often compares her two children as they grow up, causing Mia to have low self-esteem. Her husband works as a renowned lawyer.

\subsubsection{Setting}

This novel is set in various locations, mainly in the city of Surabaya. The indoor settings include Mia's apartment, boarding house, and photo studios where she works, whereas the outdoor settings include cafes, restaurants, and malls all around the city when Kyle and Mia go out together. Other than that, it also includes Kyle's house or photo studio in Jakarta. Then, at the end of the novel, the setting will also include Mia's apartment with her sister in London, especially her room.

\section{CONCLUSION}

I have learned a lot in the process of writing this novel. In the beginning, there was a part of me that doubted myself whether I could actually finish this novel in less than six months. After all, I had already tried to write a novel three times in the past, and neither of them actually made it until the end. I either got bored or lost grasp of the story somewhere in the middle. Then, other than some classes this semester, I also have a part-time job that takes quite a lot of my time. Therefore, in the course of writing - and actually finishing - this story, I learned to manage my time well, so that I could write whenever I had the time. One of the ways I did that was by giving myself personal deadlines. No matter what, I always tried my best to finish by that deadline, before moving on to the next part of the story.

Second, I also learned to do plenty of research and make an outline prior to the actual writing. In the past, I never did any research, nor did I make a proper outline of my story from start to finish. Perhaps that was also the reason why my previous attempts to write novels never succeeded. However, in writing this creative work, no matter what, I had to finish with the limited time I had. Therefore, I could no longer write whatever and whenever I wanted to like I did in the past. In the end, although having an outline seemed rather restrictive, I actually found that it helped me a lot in staying in line with the story, instead of letting my story go astray that I could no longer control where it was going. Additionally, the research also helped my story stay realistic and more enjoyable for the readers, because they could actually relate with the characters, as the events are based on real theories instead of pure fiction.

Last but not least, I also learned to edit my story, and to be brave in eliminating the parts that may not be necessary for the whole story itself. Before writing this project, I never actually edited my stories. While I might re-read them once or twice, usually it was only to check whether I had grammar mistakes. Even until now, I am still having a hard time in eliminating the parts that may not be necessary for the whole story. However, in writing this novel, I had to learn to detach myself from my story to some extent and read it from the point of view of the readers to determine which parts are actually necessary, and which parts are not. In doing so, I could make my story more compact, but still convey the messages just as strong, if not more.

\section{REFERENCES}

Ackerman, C. (2018, July 3). What is self-regulation? Definition, theory +95 skills and strategies. Positive Psychology Program. Retrieved December 16, 2018, from https://positivepsychologyprogram.com/self-regulation/

Aprilia, A. (2018, January 26). Dampak mengerikan media sosial terhadap rasa percaya diri remaja. Okezone.com. Retrieved October 15, 2018, from 
https://lifestyle.okezone.com/read/2018/01/26/196/1850711/dampak-mengerikanmedia-sosial-terhadap-rasa-percaya-diri-remaja

Barker, E. (2016, June 7). This Is the best way to overcome fear of missing out. Time. Retrieved December 18, 2018, from http://time.com/4358140/overcome-fomo/

Bullingham, L., \& Vasconcelos, A. C. (2013). 'The presentation of self in the online world: Goffman and the study of online identities. Journal of Information Science, 39(1). doi:https://doi.org/10.1177/0165551512470051

Calafiore, S. (2014, February 6). The novel or the film. The Artifice. Retrieved December 18, 2018, from https://the-artifice.com/the-novel-or-the-film/

Campbell, J. D., \& Lavalle, L. (1993). Who am I? The role of self-concept confusion in understanding the behavior of people with low self-esteem. In R. Baumeister, SelfEsteem: The Puzzle of Low Self-Regard. New York: Plenum Press. doi:10.1007/978-14684-8956-9_1

Chou, H.-T. G., \& Edge, N. (2012). They are happier and living better lives than I am: The impact of using Facebook on perceptions of others' lives. Cyberpsychology, Behavior, and Social Networking. doi: 10.1089/cyber.2011.0324

Cook, K. (2013, February 8). The new adult novel-Bridging the gap between young adult and adult fiction. The How to Write Shop. Retrieved November 14, 2018, from http://howtowriteshop.loridevoti.com/2013/02/the-new-adult-novel-bridging-the-gapbetween-young-adult-and-adult-fiction/

Crocker, J., Brook, A., Niiya, Y., \& Villacorta, M. (2007). The pursuit of self-esteem: Contingencies of self-worth and self-regulation. Journal of Personality, 74(6), 17491771. doi:10.1111/j.1467-6494.2006.00427.x

Crocker, J., Luhtanen, R. K., Cooper, M. L., \& Bouvrette, A. (2003, December). Contingencies of self-worth in college students: Theory and measurement. Journal of Personality and Social Psychology. doi: 10.1037/0022-3514.85.5.894

Dimock, M. (2018, March 1). Defining generations: Where Millennials end and postMillennials begin. Pew Research Center. Retrieved October 15, 2018, from http://www.pewresearch.org/fact-tank/2018/03/01/defining-generations-wheremillennials-end-and-post-millennials-begin/

Goffman, E. (1956). The presentation of self in everyday life. New York: Penguin Random House LLC.

Jacobson, N. (Producer), \& Lawrence, F. (Director). (2015). The hunger games: Mockingjay part 2 [Motion picture]. United States: Lionsgate.

James, W. (1890). The principles of psychology (Vol. 10). New York: Henry Holt and Company.

Kieffer, K. (2017, July 21). What is new adult fiction? well-storied. Retrieved November 14, 2018, from http://www.well-storied.com/blog/what-is-new-adult-fiction

Lind, J. (2015, March 25). Genre guide: YA contemporary romance. The Hub. Retrieved November 7, 2018, from http://www.yalsa.ala.org/thehub/2015/03/25/genre-guide-yacontemporary-romance/

Litte, J. (2015, December 25). New Adult: It's not about the sex (but don't be afraid of the sex either). Dear Author. Retrieved November 14, 2018, from https://dearauthor.com/features/letters-of-opinion/new-adult-its-not-about-the-sex-butdont-be-afraid-of-the-sex-either/

Luckinbill, T. (Producer), \& Samuels, I. (Director). (2018). Sierra Burgess is a loser [Motion picture]. United States: Netflix.

Madasari, O. (2017). The last crowd. Jakarta: Gramedia Pustaka Utama.

Naughton, J. (2014, July 11). New adult: A book category for twentysomethings by twentysomethings. Publishers Weekly. Retrieved November 8, 2018, from https://www.publishersweekly.com/pw/by-topic/industry-news/publishernews/article/63285-new-adult-matures.html/ 
Nordquist, R. (2017, May 28). First-person point of view: Glossary of grammatical and rhetorical terms. ThoughtCo. Retrieved November 8, 2018, from https://www.thoughtco.com/first-person-point-of-view-1690861

Romance. (n.d.). Retrieved December 18, 2018, from Literary Terms: https://literaryterms.net/romance/

Screencraft Admin. (2015, December 28). Five major differences between writing novels and screenplays. Screencraft. Retrieved December 18, 2018, from https://screencraft.org/2015/12/28/five-differences-between-novels-and-screenplays/

Sholihin, B. (2018). Indonesia 2018 digital landscape. Retrieved December 18, 2018, from Slideshare: https://www.slideshare.net/rumahide/indonesia-digital-landscape-2018

Steers, M.-L. N., Wickham, R. E., \& Acitelli, L. K. (2014). Seeing everyone else's highlight reels: How Facebook usage is linked to depressive symptoms. Journal of Social and Clinical Psychology, 33(8), 701-733.

Stefanone, M. A., Lackaff, D., \& Rosen, D. (2011). Contingencies of self-worth and social networking site behavior. Cyberpsychology, Behavior, and Social Networking, 14(1-2). doi: $10.1089 /$ cyber.2010.0049

Valentine, O. (2018, January 11). Top 10 reasons for using social media. globalwebindex. Retrieved December 18, 2018, from https://blog.globalwebindex.com/chart-of-theday/social-media/

Vogel, E., Rose, J. P., \& Roberts, L. (2014). Social comparison, social media, and self-esteem. Psychology of Popular Media Culture, 3(4), 206-222. doi:10.1037/ppm0000047

Widiartanto, Y. H. (2017, May 21). Instagram dinilai buruk untuk kesehatan jiwa remaja. Kompas.com. Retrieved December 18, 2018, from https://tekno.kompas.com/read/2017/05/21/09345137/instagram.dinilai.buruk.untuk.kes ehatan.jiwa.remaja

Woods, H. C., \& Scott, H. (2016). \#Sleepyteens: social media use in adolescence is associated with poor sleep quality, anxiety, depression and low self-esteem. Journal of Adolescence, 6, 41-49. doi:https://doi.org/10.1016/j.adolescence.2016.05.008 